\title{
Characterization and application of municipal solid waste incineration (MSWI) bottom ash and waste granite powder in alkali activated slag
}

Citation for published version (APA):

Gao, X., Yuan, B., Yu, Q. L., \& Brouwers, H. J. H. (2017). Characterization and application of municipal solid waste incineration (MSWI) bottom ash and waste granite powder in alkali activated slag. Journal of Cleaner Production, 164, 410-419. https://doi.org/10.1016/j.jclepro.2017.06.218

DOI:

10.1016/j.jclepro.2017.06.218

Document status and date:

Published: $15 / 10 / 2017$

Document Version:

Publisher's PDF, also known as Version of Record (includes final page, issue and volume numbers)

Please check the document version of this publication:

- A submitted manuscript is the version of the article upon submission and before peer-review. There can be important differences between the submitted version and the official published version of record. People interested in the research are advised to contact the author for the final version of the publication, or visit the $\mathrm{DOI}$ to the publisher's website.

- The final author version and the galley proof are versions of the publication after peer review.

- The final published version features the final layout of the paper including the volume, issue and page numbers.

Link to publication

\footnotetext{
General rights

- You may freely distribute the URL identifying the publication in the public portal. follow below link for the End User Agreement:

www.tue.nl/taverne

\section{Take down policy}

If you believe that this document breaches copyright please contact us at:

openaccess@tue.nl

providing details and we will investigate your claim.
}

Copyright and moral rights for the publications made accessible in the public portal are retained by the authors and/or other copyright owners and it is a condition of accessing publications that users recognise and abide by the legal requirements associated with these rights.

- Users may download and print one copy of any publication from the public portal for the purpose of private study or research.

- You may not further distribute the material or use it for any profit-making activity or commercial gain

If the publication is distributed under the terms of Article $25 \mathrm{fa}$ of the Dutch Copyright Act, indicated by the "Taverne" license above, please 


\title{
Characterization and application of municipal solid waste incineration (MSWI) bottom ash and waste granite powder in alkali activated slag
}

\author{
X. Gao ${ }^{\text {a, b, } 1 \text {, B. Yuan }}{ }^{\text {a, b, } 1}$, Q.L. Yu ${ }^{\text {a, }{ }^{*} \text {, H.J.H. Brouwers }}{ }^{\text {a, b }}$ \\ a Department of the Built Environment, Eindhoven University of Technology, P.O. Box 513, 5600 MB Eindhoven, The Netherlands \\ b State Key Laboratory of Silicate Materials for Architectures, Wuhan University of Technology, Wuhan 430070, PR China
}

\section{A R T I C L E I N F O}

\section{Article history:}

Received 17 March 2017

Received in revised form

9 June 2017

Accepted 24 June 2017

Available online 26 June 2017

\section{Keywords}

Municipal solid waste incineration bottom

ash

Granite powder

Alkali activated slag

Leaching

Reactivity

Carbon footprint

\begin{abstract}
A B S T R A C T
In this paper, the feasibility of using two solid wastes in alkali activated slag composites as construction and building materials is evaluated. One waste is the municipal solid waste incineration (MSWI) bottom ash, and the other one is fine granite powder from aggregate manufacturing. These two solid wastes are thoroughly characterized, and their effects on reaction process, gel composition, microstructure are investigated by isothermal calorimeter, TG/DSC, FTIR and SEM. Leaching properties and $\mathrm{CO}_{2}$ footprint of some typical mixes are evaluated. The results indicate that both bottom ash and granite addition can be regarded as non-reactive phases. Micro scale analyses show no evident chemical involvement of both wastes on the gel structure of the reaction products. Bottom ash addition reduces the compressive strength, and granite powder presents a lower influence; $28 \mathrm{~d}$ strengths of around 20-70 MPa can be achieved depending on the replacement levels. Most of the mixtures pass the Dutch regulation for heavy metal leaching, while the excessive chlorides and sulfates contents can be easily treated by methods such as washing. The carbon emission is significantly reduced due to the negative impact of the waste solids, and this value can be further lower if bottom ash with larger sizes is used to replace coarse aggregates. Therefore, these two solid wastes present promising application potential based on the identified performances and sustainability.
\end{abstract}

๑) 2017 Elsevier Ltd. All rights reserved.

\section{Introduction}

It is commonly known that the Portland cement production is accompanied with high carbon emissions that are responsible for approximately $7 \%$ of the global $\mathrm{CO}_{2}$ emissions (Capros et al., 2001) and energy costs (Friedlingstein et al., 2010). While in the European Union, the building materials sector is the third-largest $\mathrm{CO}_{2}$ emitting contributor (UNSTATS, 2010). In order to reduce the negative environmental impacts, great efforts have been made during the past decades. Among those researches, the utilization of alkali activated material (AAM) as an alternative binder has attracted great attention because of its excellent mechanical properties (Wang et al., 1994), durability, thermal stability together with low environmental impacts compared to Portland cement (Weil et al., 2009). This type of material is usually produced by mixing alkaline activator solutions with solid raw materials. The most widely

\footnotetext{
* Corresponding author.

E-mail address: q.yu@bwk.tue.nl (Q.L. Yu).

1 Equivalent first authors.
}

applied activator solutions are sodium hydroxide modified with sodium silicate, and the commonly used starting solid materials are slag, fly ash and metakaolin. Besides, the effects of key synthesizing factors on reaction kinetics (Gao et al., 2015), gel characteristics (Li et al., 2010), mechanical properties and durability issues (Bernal et al., 2012) for the alkali activated systems were intensively investigated; also their ability to bind heavy metals was also observed (Zhang et al., 2007).

Besides the applications of alternative binders, the reuse of solid wastes in construction and building materials can also greatly contribute to sustainable development. One typical waste material is the municipal solid waste incineration (MSWI) bottom ash (BA). This is a by-product from municipal solid waste incineration, which may contain glass, metals, ceramics, minerals, stone, brick, and unburned organics (Chimenos et al., 1999). The incineration process shows benefits in massive reduction of the solid household wastes (Bosmans et al., 2013), energy reuse (Cimpan and Wenzel, 2013) and recycling of certain metals, paper and plastics (Wiles, 1996). And the resulting bottom ash is encouraged to be reused as a secondary building material in Europe especially considering the rapidly increased amount of land filling and to reduce the usage of 
natural gravels. In addition, applications of bottom ash as aggregate substitute in cement based materials were successfully carried out (Forteza et al., 2004; Lee et al., 2010).

However, there exists several significant drawbacks that limit the wide application of this waste material: generated cracks due to the presence of metallic aluminium (Bertolini et al., 2004), obvious alkali-silica reaction because of the glass residues (Juric et al., 2006) and leaching of heavy metals (Hjelmar et al., 2007). The primary environmental issue of MSWI BA comes from the leaching of heavy metals that could lead to severe damage on water resources (Birgisdottir et al., 2006) and human health (Song et al., 2013). In the Netherlands, a national regulation termed Soil Quality Decree limits the amount of leachable contaminants from construction materials in order to control the potential negative environmental impacts (Eikelboom et al., 2001). Thus appropriate treatments are usually required before a certain application. Besides, another ground solid waste is the granite powder, which comes from the crushing and washing of high quality granite aggregates. Compared to waste bottom ash, it contains no risky contaminants to the environment but brings pressure to land filling. Therefore, a suitable application of these two solid wastes in construction and building materials will be of great benefit in reducing the environmental impacts.

It was reported that the alkali activated materials are proper binders to immobilize the heavy metals in bottom ash. For instance, the effective binding of $\mathrm{Cr}, \mathrm{Cd}, \mathrm{Zn}$ and $\mathrm{Pb}$ in calcium enriched alkali activated slag (Jan, 2002), and $\mathrm{Pb}, \mathrm{Cr}, \mathrm{Cu}$ and $\mathrm{Sn}$ in aluminosilicates dominated geopolymers (Rozineide et al., 2016). It suggests that reusing bottom ash in alkali activated systems shows convenience in heavy metal treatment, which further results in reduced costs and wider applications. Depending on the nature and particle sizes of bottom ash, it shows the feasibility to be partial replacement of both binder (Chen et al., 2016) and aggregate (Xie and Ozbakkaloglu, 2015). Besides, although limited attention was paid to reusing the granite powder, its similar origin to limestone powder may indicate an analogical application potential, which benefits both Portland cement and alkali activated binders by reducing the binder dosage and refining the pore structure (Bonavetti et al., 2001). As can be noticed, previous researches mainly focused on identifying the possibility of reusing bottom ash in alkali activated materials and the heavy metal binding effect; while limited attention was paid to the chemical effect of bottom ash on this new binding system such as early age reaction and gel composition. Also specific environmental issues such as carbon footprint and energy cost of the alkali binder-solid waste composites are rarely discussed.

The objective of this study is to carry out a comprehensive study on reusing two solid wastes, bottom ash and granite powder, as replacements of either binder or aggregate in alkali activated materials, and evaluating the performances from micro to macro scale and identifying the environmental footprint of the final product. Firstly a systematic characterization of the starting materials is carried out, then suitable waste material dosages and their effects on reaction kinetics, mechanical properties, gel structure, micrograph and leaching behavior of the reaction products are investigated. Subsequently, the total carbon footprint of this system is evaluated and discussed.

\section{Experiment}

\subsection{Materials}

The solid precursor used in this study was ground granulated blast furnace slag. The major chemical compositions were analyzed by X-ray fluorescence and are shown in Table 1. The MWSI bottom ash used in this study was obtained from a local municipal solid waste incineration plant. The particles lower than $2 \mathrm{~mm}$ were used
Table 1

XRF analysis of waste bottom ash, granite powder and slag (wt. \%).

\begin{tabular}{|c|c|c|c|}
\hline Chemical compositions & Bottom ash & Granite powder & Slag \\
\hline $\mathrm{Na}_{2} \mathrm{O}$ & 2.359 & 2.025 & 0.35 \\
\hline $\mathrm{MgO}$ & 2.116 & 3.441 & 9.05 \\
\hline $\mathrm{Al}_{2} \mathrm{O}_{3}$ & 12.037 & 16.681 & 12.58 \\
\hline $\mathrm{SiO}_{2}$ & 19.122 & 57.499 & 30.23 \\
\hline $\mathrm{P}_{2} \mathrm{O}_{5}$ & 2.625 & 0.045 & 0.03 \\
\hline $\mathrm{SO}_{3}$ & 2.393 & 0.117 & 1.47 \\
\hline $\mathrm{K}_{2} \mathrm{O}$ & 0.848 & 4.518 & 0.43 \\
\hline $\mathrm{CaO}$ & 43.115 & 9.129 & 40.51 \\
\hline $\mathrm{TiO}_{2}$ & 2.48 & 0.835 & 1.01 \\
\hline $\mathrm{Cr}_{2} \mathrm{O}_{3}$ & 0.15 & 0.029 & \\
\hline $\mathrm{MnO}$ & 0.196 & 0.111 & 0.33 \\
\hline $\mathrm{Fe}_{2} \mathrm{O}_{3}$ & 9.313 & 5.35 & 0.6 \\
\hline $\mathrm{NiO}$ & 0.042 & 0.006 & \\
\hline $\mathrm{CuO}$ & 0.872 & 0.002 & \\
\hline $\mathrm{ZnO}$ & 1.287 & 0.01 & \\
\hline $\mathrm{SrO}$ & 0.132 & 0.003 & \\
\hline $\mathrm{ZrO}_{2}$ & 0.035 & 0.02 & \\
\hline $\mathrm{Ag}_{2} \mathrm{O}$ & 0.158 & 0.073 & \\
\hline $\mathrm{BaO}$ & 0.239 & 0.104 & \\
\hline $\mathrm{PbO}$ & 0.317 & 0.004 & \\
\hline $\mathrm{Cl}$ & 0.166 & & 0.011 \\
\hline
\end{tabular}

in this study, while these particle fractions are difficult to apply in Portland cement system because of the high content of heavy metals. A granite powder slurry (provided by Graniet-Import Benelux, the Netherlands) was used as a filler. Detailed characterizations of these two waste materials will be presented in Section 3.1. Besides, standard CEN sand was used as fine aggregates. Concerning the alkaline activator, a mixture of sodium hydroxide (analytical level of $99 \mathrm{wt} . \%$ ) and a commercial waterglass solution (27.69\% $\mathrm{SiO}_{2}, 8.39 \% \mathrm{Na}_{2} \mathrm{O}$ and $63.92 \% \mathrm{H}_{2} \mathrm{O}$ by mass) was used. The desired activator modulus ( $\mathrm{Ms}, \mathrm{SiO}_{2} / \mathrm{Na}_{2} \mathrm{O}$ molar ratio) was achieved by adding the appropriate amount of sodium hydroxide into the sodium silicate solution. Distilled water was added in order to reach the desired water/binder ratio. The mixed activator solution was cooled down to room temperature for $24 \mathrm{~h}$ before further use.

\subsection{Sample preparation}

The activator used in this study had an equivalent sodium oxide $\left(\mathrm{Na}_{2} \mathrm{O}\right)$ content of $5 \%$ by mass of the binder and an activator modulus of 1.4. The target activator modulus was reached by mixing sodium silicate solution and sodium hydroxide pellets with a solution/pellets mass ratio of 6.41. The used water/powder ratios were 0.5 and 0.55 , the water consisted of the added distilled water and the water contained in the activator solution. Incinerated waste bottom ash contents up to $50 \%$ (by volume of the fine aggregates) and granite powder contents up to $20 \%$ (by volume of the binder) was applied. The mix proportions of the used materials are listed in Table 2. All mortar specimens were prepared in a laboratory mixer. Firstly the solid precursors were added into the mixer and mixed for $1 \mathrm{~min}$, followed by the activating solution; their mixtures were mixed at a slow speed for $30 \mathrm{~s}$ and retained for $30 \mathrm{~s}$ before another $120 \mathrm{~s}$ at a medium speed. Then the fine fillers and aggregates were added with another $120 \mathrm{~s}$ of mixing. The fresh mortar was then poured into plastic molds of $40 \times 40 \times 160 \mathrm{~mm}^{3}$ and vibrated for $1 \mathrm{~min}$, covered with a plastic film on the top surface for $24 \mathrm{~h}$; finally all specimens were demolded and cured at a temperature of $20^{\circ} \mathrm{C}$ and a relative humidity of about $95 \%$ until their testing age.

\subsection{Testing methods}

The reaction kinetics was studied by an isothermal calorimeter (TAM Air, Thermometric). All measurements were conducted for 
Table 2

Mix proportions of mixtures for the strength test $\left(\mathrm{kg} / \mathrm{m}^{3}\right)$.

\begin{tabular}{|c|c|c|c|c|c|}
\hline \multirow[t]{2}{*}{ Mixtures } & \multicolumn{2}{|c|}{ Binder content } & \multicolumn{2}{|c|}{ Aggregate content } & \multirow[t]{2}{*}{$\mathrm{w} / \mathrm{p}$} \\
\hline & Slag & Granite powder & Bottom ash & Sand & \\
\hline$S$ & 450 & 0 & 0 & 1350 & $0.5 / 0.55$ \\
\hline $\mathrm{S}+10 \mathrm{BA}$ & 450 & 0 & 97.2 & 1215 & 0.5 \\
\hline $\mathrm{S}+20 \mathrm{BA}$ & 450 & 0 & 194.4 & 1080 & \\
\hline $\mathrm{S}+30 \mathrm{BA}$ & 450 & 0 & 291.6 & 945 & \\
\hline $\mathrm{S}+40 \mathrm{BA}$ & 450 & 0 & 388.8 & 810 & \\
\hline $\mathrm{S}+5 \mathrm{GP}$ & 427.5 & 20.9 & 0 & 1350 & \\
\hline$S+10 G P$ & 405 & 41.8 & 0 & 1350 & \\
\hline$S+15 G P$ & 382.5 & 62.7 & 0 & 1350 & \\
\hline $\mathrm{S}+20 \mathrm{GP}$ & 360 & 83.6 & 0 & 1350 & \\
\hline $\mathrm{S}+25 \mathrm{BA}$ & 450 & 0 & 243 & 1012.5 & 0.55 \\
\hline $\mathrm{S}+25 \mathrm{BA}+10 \mathrm{GP}$ & 405 & 41.8 & 243 & 1012.5 & \\
\hline $\mathrm{S}+25 \mathrm{BA}+20 \mathrm{GP}$ & 360 & 83.6 & 243 & 1012.5 & \\
\hline $\mathrm{S}+50 \mathrm{BA}$ & 450 & 0 & 486 & 675 & \\
\hline $\mathrm{S}+50 \mathrm{BA}+10 \mathrm{GP}$ & 405 & 41.8 & 486 & 675 & \\
\hline $\mathrm{S}+50 \mathrm{BA}+20 \mathrm{GP}$ & 360 & 83.6 & 486 & 675 & \\
\hline
\end{tabular}

$72 \mathrm{~h}$ under a constant temperature of $20^{\circ} \mathrm{C}$. The compressive strength testing was carried out according to EN 196-1 (2005). $40 \times 40 \times 40 \mathrm{~mm}^{3}$ cubes were prepared and tested at the ages of 7 and $28 \mathrm{~d}$. The effect of granite powder and waste bottom ash on gel structure was analyzed by using Fourier transform infrared spectroscopy (FTIR) in a Varian 3100 instrument with the wavenumbers ranging from 4000 to $600 \mathrm{~cm}^{-1}$ at a resolution of $1 \mathrm{~cm}^{-1}$; together with thermogravimetry and differential scanning calorimetry (TG/ DSC) analysis in a STA 449-F1 instrument, ground powder samples were heated to $1000{ }^{\circ} \mathrm{C}$ at the heating rate of $5{ }^{\circ} \mathrm{C} / \mathrm{min}$ with nitrogen as the carrier gas. Both FTIR and TG/DSC tests are carried out on samples without standard CEN sand, after $28 \mathrm{~d}$ of curing. The leaching test following NEN 7383 (2003) was performed using a column leaching test with a liquid/solid ratio of $10 \mathrm{l} / \mathrm{kg}$. Samples were crushed with particle sizes lower than $4 \mathrm{~mm}$ and placed in the testing column. Water was forced to flow through the particles for a $24 \mathrm{~h}$. The concentration of chemical elements, the amounts of chloride and sulfate ions were analyzed using the ICP-AES according to NEN 6966 (2005) and HPLC following NEN 10304-2 (1996), respectively. Finally, the results were compared to the limited leaching values based on the Dutch legislation (Soil Quality Decree, 2008). The microstructure of the reaction products was characterized by scanning electron microscopy (SEM), using a JEOL JSM-IT100 instrument operating in a high vacuum mode at an accelerating voltage of $10 \mathrm{kV}$. Reacted mortar specimens after $28 \mathrm{~d}$ of curing were cut into fine reactions, dried and coated with a thin gold layer before testing.

\section{Results and discussion}

\subsection{Characterization of waste materials}

A detailed characterization of the MSWI bottom ash and granite powder was carried out. The moisture contents and densities were firstly identified. For the moisture content test, bottom ash and granite powder from different areas of the container were sampled and heated up to $105 \pm 5{ }^{\circ} \mathrm{C}$ until the mass was constant. The average moisture content (of nine samples) for bottom ash and granite powder is $20.6 \%$ and $20.8 \%$, respectively. The high free water content of bottom ash and granite powder slurry should be carefully considered during the design process. For the bottom ash, it can be used after evaporating the free water or applied directly by taking its water content into account. Considering the granite powders, it should be noted that the high free water content together with its fine particles may cause difficulties in dispersion of this material during the mixing. Thus a drying process or a premixing/dispersion process is suggested. While in this study, waste bottom ash was dried to exclude the free water, in order to achieve a constant starting condition. The sticky granite powder was firstly dispersed in water with the addition of a superplasticizer, and this pre-dispersion process resulted in a well dispersed granite powder in water, which can be applied directly in mortar manufacturing. Their specific densities were measured by using the gas intrusion method employing an AccuPyc 1340 II Pycnometer, after drying. The measured value is an average of three samples, which is $2.72 \mathrm{~g} \mathrm{~cm}^{-3}$ for bottom ash and $2.74 \mathrm{~g} \mathrm{~cm}^{-3}$ for granite powder, respectively. Those values are similar to the commonly used fine aggregates and hydraulic materials such as slag, making it convenient in the designing processes that are based on both mass and volume.

The detailed particle size distributions (PSD) of the bottom ash and granite powder are shown in Fig. 1, together with the other applied solids. The PSD of granite was measured in liquid dispersion using the Mie scattering model as the measuring principle following ISO 13320 (2009); while the bottom ash was analyzed by sieve analysis according to the standard EN 933-1 (1997). It can be seen that the granite powder shows a particle size range from $100 \mathrm{~nm}$ to $400 \mu \mathrm{m}$, with a medium particle size of around $10 \mu \mathrm{m}$, which is similar to the commonly used powder additives. Concerning the bottom ash, it shows a medium particle size of around $800 \mu \mathrm{m}$ and a size range from $10 \mu \mathrm{m}$ to $2000 \mu \mathrm{m}$. It should be noticed that a certain amount of smaller particles may aggregate with each other to form bigger ones, and those aggregated particles easily break during the sieving process, thus pre-treatments might be needed when applying them.

Fig. 2 presents the SEM picture of the waste bottom ash. Bottom ash particles with different sizes and shapes are observed, which are mainly a physical combination of various types of incinerated residues from urban wastes. Large amounts of pores are also identified, which is partly due to the nature of those starting materials, and partly caused by the incineration process. The porous structure will negatively influence the mechanical strength of the bottom ash when used as aggregates, and increase the water demand to some extent. However, if a suitable mix design is applied; those drawbacks can be largely reduced. Besides, porous aggregates are known to promote the late hydration process by the effect of

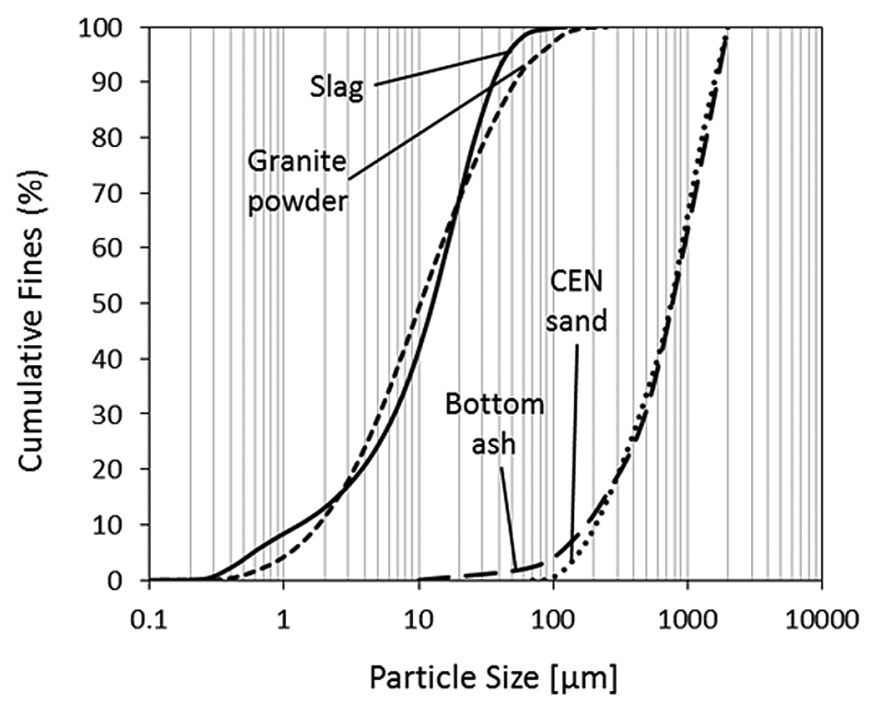

Fig. 1. Particle size distributions of Bottom ash and Granite powder. 


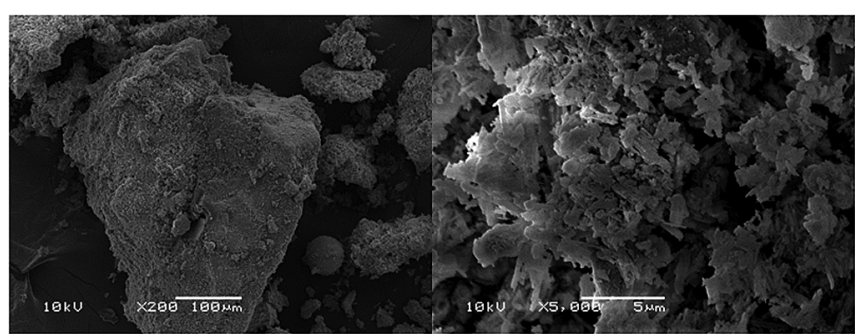

Fig. 2. SEM picture of the bottom ash.

internal curing, and how this bottom ash affects the reaction process in the long term is another research interest.

The chemical compositions of bottom ash and granite powder are listed in Table 1, and their XRD patterns are shown in Fig. 3. It shows that the granite powder mainly contains $\mathrm{Si}, \mathrm{Al}$ and $\mathrm{Ca}$; and limited amounts of heavy metals and sulfates. While the main mineral components identified are quartz $\left(\mathrm{SiO}_{2}\right)$, calcite $\left(\mathrm{CaCO}_{3}\right)$, plagioclase $\left(\mathrm{NaAlSi}_{3} \mathrm{O}_{8}-\mathrm{CaAl}_{2} \mathrm{Si}_{2} \mathrm{O}_{8}\right)$, and $\mathrm{k}$-feldspars including orthoclase $\left(\mathrm{KAlSi}_{3} \mathrm{O}_{8}\right)$. All those minerals, except for calcite, are typical compositions of natural granite, thus the granite powder in this case can be generally regarded as a mixture of natural granite and calcite powder. In the case of the bottom ash, the primary elements are also $\mathrm{Ca}, \mathrm{Si}$ and $\mathrm{Al}$, but with different contents compared to granite powder. Certain amounts of environment related components are presented such as heavy metals, chloride and sulfates, which should be carefully handled before application. The major minerals observed are calcite, and small amount of quartz and magnetite.

\subsection{Reaction kinetics}

The compositional analyses have shown that both MSWI bottom ash and granite powder contain high amounts of $\mathrm{CaO}, \mathrm{SiO}_{2}$ and $\mathrm{Al}_{2} \mathrm{O}_{3}$, also crystalline phases containing these mineral oxides are clearly observed. While in the case of alkali activated system, any starting material that contains reactive $\mathrm{Ca}, \mathrm{Si}$ and $\mathrm{Al}$ can be used for activation. Therefore, identifying the reactivity of waste bottom ash and granite powder is of importance since they have the potential to be applied as a binder substitute. The isothermal calorimeter is used in order to investigate the effect of these two solid wastes on the early age reaction process of the basic cementitious system. Fig. 4 shows the normalized heat flow of six mixes within the first $72 \mathrm{~h}$. The heat flow is normalized by mass of the binding material (slag), except for samples containing only Granite or bottom ash

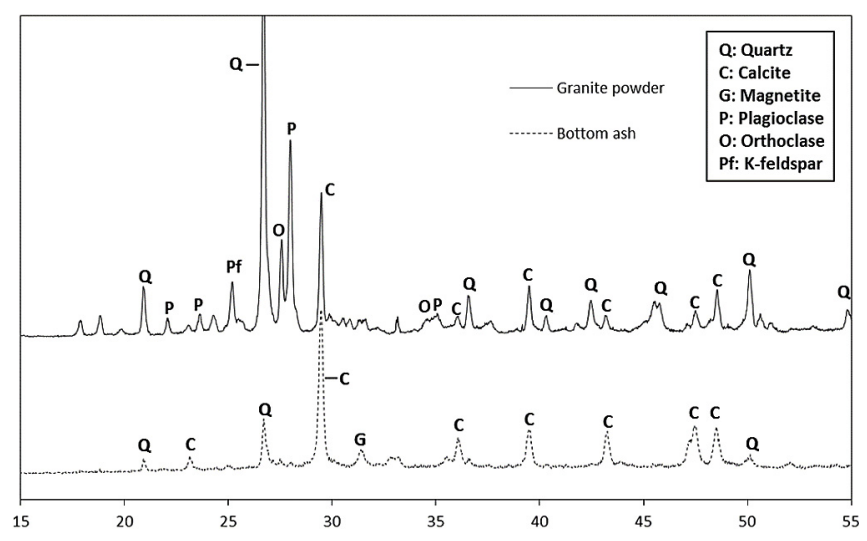

Fig. 3. XRD patterns of Bottom ash and Granite powder.

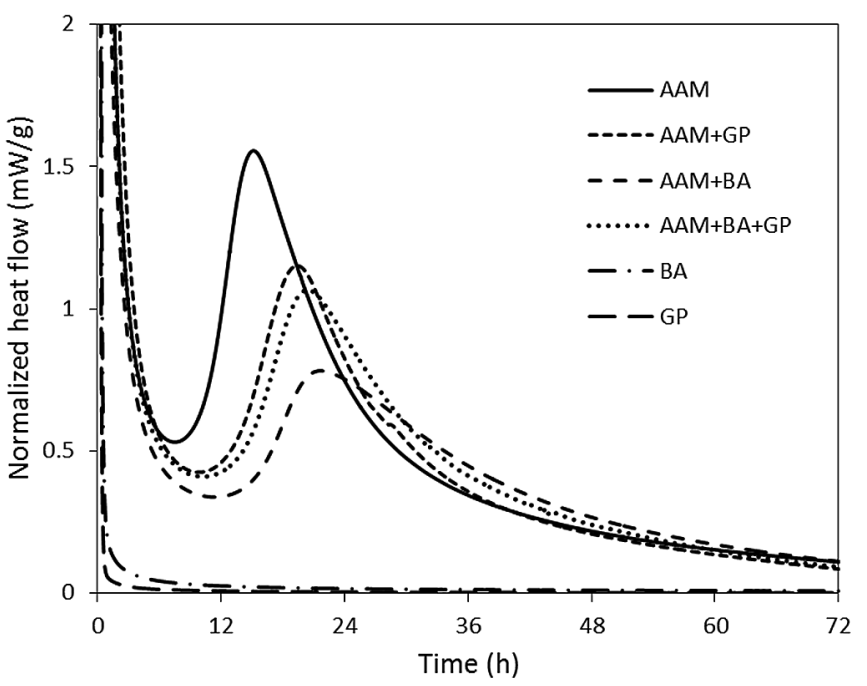

Fig. 4. Normalized heat flow of alkali activated materials, waste bottom ash and granite powder.

that are normalized by mass of the Granite or bottom ash. The used activator has a $\mathrm{Na}_{2} \mathrm{O}$ dosage of $5 \%$ and total water to powder ratio of 0.5 , which are the same parameters as used in the mortar samples. Samples labeled with "BA" and "GP" refer to the ones that contain purely waste bottom ash or granite powder that is mixed with the alkali activator, while "AAM" refers to the alkali activated materials.

The typical reaction process of alkali activated materials can be classified into four stages: initial dissolution, induction, acceleration/deceleration and stable period. The initial peak with significant high heat flow refers to the initial wetting and dissolution of raw materials, while the second peak is attributed to the massive formation of reaction products (Shi and Day, 1995). It can be seen that the alkali activated slag exhibits obvious reaction peaks at around $14 \mathrm{~h}$, also with significantly higher heat flow than bottom ash and granite powder, revealing the occurrence of chemical reaction.

The difference in reactivity is also shown in the cumulative heat evolution curves in Fig. 5, where slag mix presents a continuously increased heat release, while different total heat release.

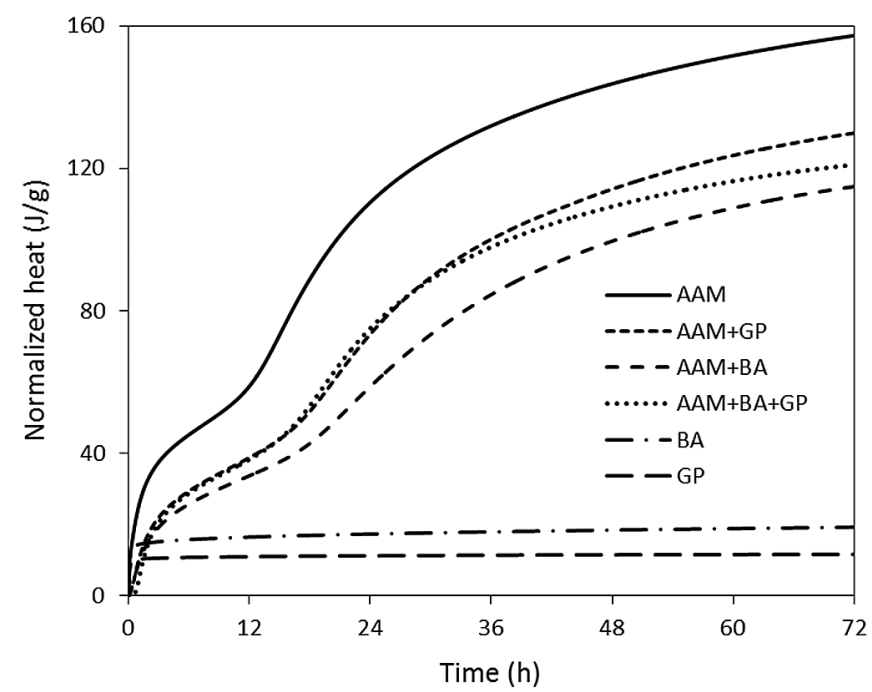

Fig. 5. Cumulative heat release of alkali activated materials, waste bottom ash and granite powder. 
Concerning the bottom ash and granite powder, both waste materials show negligible heat release after the initial dissolution, and the total heat release no longer increases afterwards. It indicates that these two materials may only work as non-reactive phases under alkali activation. This phenomenon is against the results from the literature that the potential reactivity of waste bottom ash was observed in both alkali activated systems (Lancellotti et al., 2013) and Portland cement systems (Tang et al., 2016). Considering the variations of the starting materials, an evaluation of the reactivity before application is suggested to be highly necessary. It is also believed that the origin of the starting waste materials and the incineration process play a key role on determining the reactivity of the MWSI bottom ash.

The effect of the two solid wastes on the reaction of slag can be presented by investigating the mixture of them with slag. "AAM+GP" and "AAM+BA" refer to the mixture of granite powder and bottom ash addition by $20 \%$ of the slag, respectively. As shown in Fig. 4, the main reaction peak for alkali activated slag is delayed from around $14.4 \mathrm{~h}-18.4 \mathrm{~h}$ with a reduced intensity when granite powder is added. The reduced intensity can be explained by the decreased total amount of slag in the system, while the prolonged induction time together with delayed main reaction peak suggest that the granite powder replacement slightly delays the formation of reaction products. Compared to the mix of "AAM+GP", a more significant reduction in peak intensity and delayed presence of main reaction peak is found in mix "AAM+BA", where the bottom ash has the same replacement level as granite powder, which indicates that the waste bottom ash exhibits a higher impact on the reaction process than granite powder. The inhibited reaction can be partly explained by the porous structure of bottom ash, which may absorb certain amounts of activator solution during the mixing, and therefore less activator is provided to activate slag. It is easy to understand that the mixture with both bottom ash and granite powder addition (AAM+BA+GP) presents a moderate inhibiting effect, since the total solids waste content are fixed at $20 \%(10 \%$ BA $+10 \%$ GP). The cumulative heat release presents the similar tendency as the heat flow results, while the addition of solid wastes reduces the total heat release, and waste bottom ash presents a more significant influence on the reaction process than granite powder.

\subsection{Compressive strength}

The 7 and $28 \mathrm{~d}$ compressive strengths of mixtures with different waste bottom ash and granite powder contents are depicted in Fig. 6. All mixes are having a water to powder ratio of 0.5 . For the reference sample, the compressive strength is $56.2 \mathrm{MPa}$ at $7 \mathrm{~d}$, and it increases to 69.6 MPa after $28 \mathrm{~d}$ of curing. When waste bottom ash is incorporated to replace fine aggregates, there is a continuous decrease in strength from 56.2 MPa to 27.5 MPa at $7 \mathrm{~d}$ and from 69.6 MPa to $34.61 \mathrm{MPa}$ at $28 \mathrm{~d}$. It should be noted that the strength decrement between 7 and $28 \mathrm{~d}$ is significant within the bottom ash content of $20 \%$, while the strength shifts become relatively mild in mixes with bottom ash content from $20 \%$ to $40 \%$. The obvious reduction in strength can be attributed to the porous structure of waste bottom ash after incineration, and therefore a lower strength of this aggregate. The reduced bond strength between aggregates and the binder (interfacial transition zone) can be another reason for the reduced compressive strength, which is caused by the relatively fragile structure of bottom ash (i.e. a low crushing strength) compared to the natural fine aggregates. Besides, it should be noted that the metallic aluminate from the bottom ash usually causes cracking and sometimes even initial failure when it is applied without suitable treatment (Aubert et al., 2004); while in the alkali activated system, no expansion and cracking were

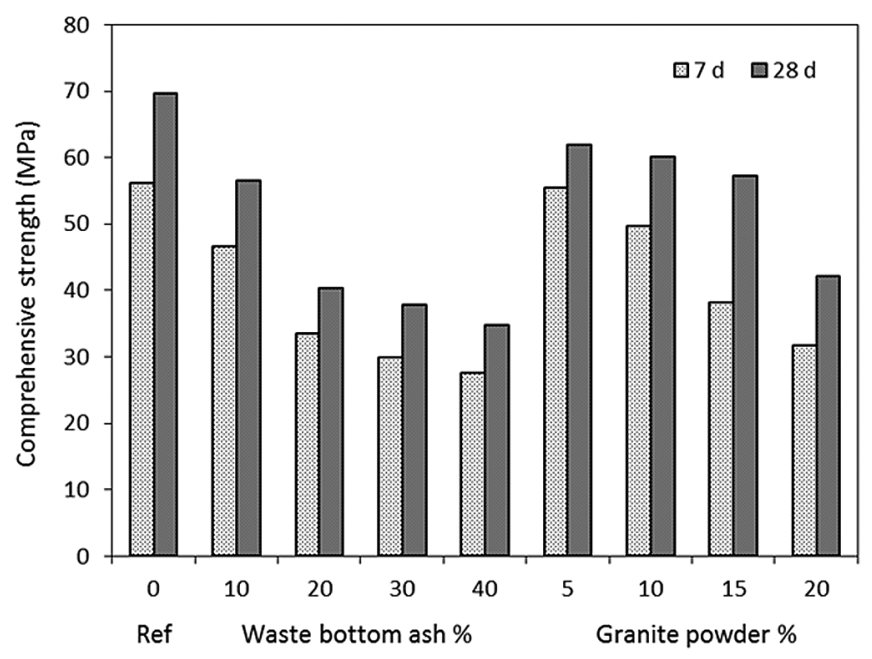

Fig. 6. Compressive strength of alkali activated materials with bottom ash or granite powder $(\mathrm{w} / \mathrm{p}=0.5)$.

observed. It is suggested that this is due to the high alkali concentration (with $\mathrm{pH}$ value above 13) of the activators at the initial stage of mixing, which will dissolve those aluminates and reduce/ eliminate the expansion. Those dissolved aluminates may also contribute to the reaction process since the alumina is one of the starting components of the alkali activated system. In addition, since the aluminate has no negative effect on the binder matrix and its extraction process can be ignored, the application of this bottom ash can be more cost effective. The effect of the metallic aluminate from bottom ash on the reaction process is an interesting issue, and it will be investigated in detail in future studies.

Concerning the effect of granite powder, the replacement up to $15 \%$ leads to a gradual decrease of strength from $69.6 \mathrm{MPa}$ to $57.1 \mathrm{MPa}$ (by $18 \%$ ) after $28 \mathrm{~d}$ of curing. Further increment up to $20 \%$ results in a more obvious reduction of strength to $41.9 \mathrm{MPa}$. The effect of granite powder content on strength can be partly explained the filler effect: on the one hand the granite powder works as micro aggregates, reducing the total porosity and benefiting the strength; while on the other hand, its increased content negatively influences the binding matrix, resulting in strength reduction. The optimal dosage may vary from case to case. It should be noted that in Portland cement system, the suitable limestone powder content of up to $10 \%$ is usually observed, showing a similar tendency as the granite powder in this study. The replacement of granite powder within a reasonable range reduces the binder dosage in alkali activated system, and therefore reduces the total costs of the final products; also the reuse of this waste material contributes to the sustainable development.

The effect of hybrid usage of bottom ash and granite powder on compressive strength is shown in Fig. 7. In order to show the combined effect of those two materials on the strength, the bottom ash contents of $25 \%, 50 \%$ and granite powder contents of $10 \%, 20 \%$ are chosen, based on the results of their individual effect on strength. The used water to powder ratio is fixed at 0.55 . Compared to the results from Fig. 6, the increase of water to powder ratio leads to an obvious strength reduction in general. The reference sample shows a $7 \mathrm{~d}$ strength of $42.5 \mathrm{MPa}$ and it increases to $52.0 \mathrm{MPa}$ at $28 \mathrm{~d}$. Similarly, the addition of bottom ash results in a significant reduction of strength at both 7 and $28 \mathrm{~d}$, because of its porous structure. For a fixed bottom ash content, the $10 \%$ replacement of granite powder only leads to a slight decrease of strength, and further increment to $20 \%$ presents very limited influence. Mixtures with bottom ash/granite powder additions of $25 / 20$ and 50/20 


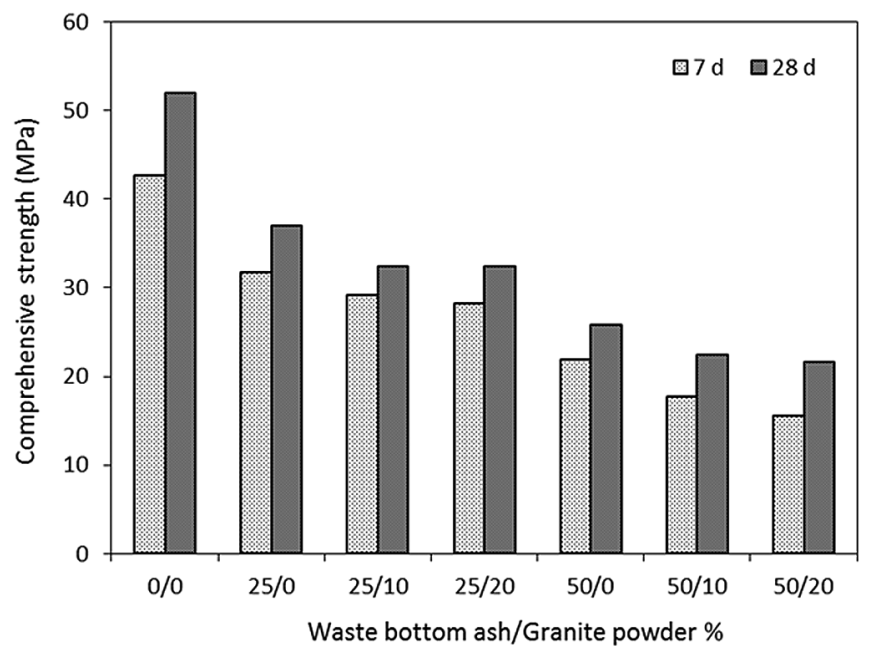

Fig. 7. Compressive strength of alkali activated materials with bottom ash and granite powder $(\mathrm{w} / \mathrm{p}=0.55)$.

show compressive strengths of $32.3 \mathrm{MPa}$ and 21.6 MPa, respectively. Additionally, it should be noticed that the addition of porous or fine particles would decrease the flow ability of the fresh samples, which also shows an effect on the mechanical properties (Huiskes et al., 2016). In the present study, increasing the bottom ash content up to $40 \%$ in the reference mix results in a reduction of slump flow from $21.5 \mathrm{~cm}$ to $18.9 \mathrm{~cm}$. Similarly, the flowability reduces to $19.2 \mathrm{~cm}$ with the granite powder replacement of $20 \%$. In summary, although significant reductions in strength are observed when large amounts of bottom ash are applied, the compressive strength range in this study shows excellent applicability for many applications; while suitable granite powder addition reduces cement consumption and shows limited influence on strength. Thus both solid wastes present promising application potentials.

\subsection{Gel structure identification}

Fig. 8 shows the infrared spectra of the unreacted slag, granite powder and waste bottom ash. The slag presents a broad main vibration band at around $900 \mathrm{~cm}^{-1}$, which is associated with the vibration of $\mathrm{Si}-\mathrm{O}$ bond, also a small absorption band at around $690 \mathrm{~cm}^{-1}$, due to the asymmetric stretching vibration of T-O groups (Kovalchuk et al., 2007). Concerning the two solid wastes, both material exhibits a significant band at around $1450 \mathrm{~cm}^{-1}$ that assigned to the O-C-O bonds (Yousuf et al., 1993), indicating a certain amount of carbonates within the raw materials. A sharp absorption peak at around $880 \mathrm{~cm}^{-1}$ and a small shoulder at about $1180 \mathrm{~cm}^{-1}$ are also shown in both solids, corresponding to the $\mathrm{Mg}$
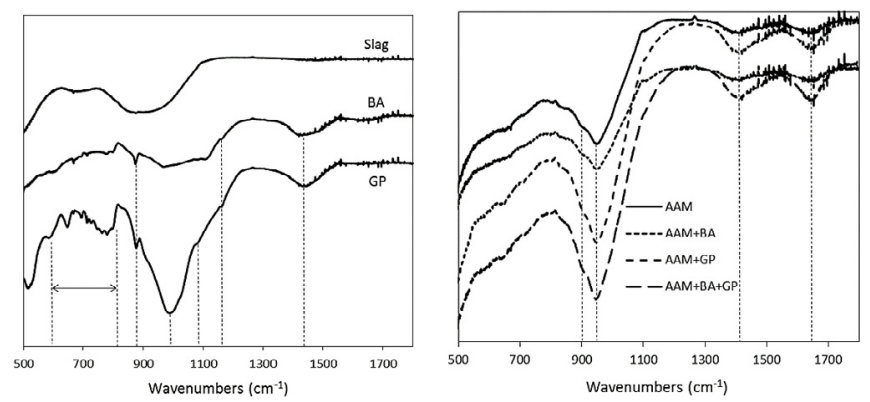

Fig. 8. FTIR spectra of alkali-activated materials with bottom ash and Granite powder addition. incorporated $\mathrm{Si}-\mathrm{O}$ bond (Bobrowski et al., 2012) and bridge $\mathrm{Si}-\mathrm{O}$ bonds in crystalline phases (Ismail et al., 2014). The waste bottom ash exhibits a terminal $\mathrm{Si}-\mathrm{O}$ bond at $980 \mathrm{~cm}^{-1}$ and a bridge one at around $1120 \mathrm{~cm}^{-1}$; while the granite powder shows an obvious bridge $\mathrm{Si}-\mathrm{O}$ bond at $1000 \mathrm{~cm}^{-1}$ and $1090 \mathrm{~cm}^{-1}$, which refer to the crystalline phases within the granite. Several vibration bonds that are observed between 600 and $800 \mathrm{~cm}^{-1}$ indicate the presence of asymmetric stretching $\mathrm{Si}-\mathrm{O}-\mathrm{T}$ bonds with slight structural differences (see the XRD spectrum in Fig. 3). Upon activation, all mixtures show the presence of bound water at $1640 \mathrm{~cm}^{-1}$ (Bernal et al., 2011), and the $\mathrm{O}-\mathrm{C}-\mathrm{O}$ from carbonates at $1450 \mathrm{~cm}^{-1}$. It can be noticed that mixtures containing waste bottom ash present a more significant peak absorption at 1640 and $1450 \mathrm{~cm}^{-1}$, suggesting a greater contribution in bound water (due to the porous structure and the resulting absorbed physically bound water) and carbonates (see the XRF analysis in Table 1). The main absorption band for the reaction product is at around $940 \mathrm{~cm}^{-1}$, assigning to the asymmetric stretching vibration of $\mathrm{Si}-\mathrm{O}$ terminal bonds (Hajimohammadi et al., 2011), which is a typical band that indicates the formation of C-A-S-H type gels with chain structures. The incorporation of both bottom ash and granite powder shows insignificant effect on the structure characters of the reaction products, the addition of granite powder increases the intensity of main absorption band, because of the obvious band in the raw material that at the same location.

In order to further characterize the effect of waste solids on gel structure, TG/DSC analyses were carried out and the results are shown in Fig. 9. All samples present an evident mass loss around $110{ }^{\circ} \mathrm{C}$, attributed to the loss of physically bound water; except for granite powder, which exhibits one obvious mass loss of around $5 \%$ between $600{ }^{\circ} \mathrm{C}$ and $800{ }^{\circ} \mathrm{C}$, due to the decomposition of carbonates. While the MSWI bottom ash presents a continuous mass loss of about $15 \%$, up to $1000{ }^{\circ} \mathrm{C}$, it is difficult to identify those phases in detail because of the complex origin of the starting wastes. As for the alkali activated materials (AAM), the continuous mass loss after around $200{ }^{\circ} \mathrm{C}$ is assigned to the gradual decomposition of the reaction products, while the mass loss between $600{ }^{\circ} \mathrm{C}$ and $800{ }^{\circ} \mathrm{C}$ indicates a certain degree of carbonation during the reaction or curing process. When granite powder and bottom ash were both added, mixtures exhibit similar tendency of mass loss and typical mass loss regions, suggesting similar gel composition characteristics. The incorporation of these two solid wastes increases the overall mass loss up to $1.2 \%$, attributed to the original mass loss of the two solids. Together with the calorimeter and FTIR results in this study, it can be concluded that although the addition of the waste solids reduces the strength and delays the early age reaction, they present a negligible chemical influence on the binder structure. The DSC (differential scanning calorimeter) results are presented in Fig. 9 (b), the sharp heat absorption peak at $110{ }^{\circ} \mathrm{C}$ is associated with the evaporation of physically bound water. The exothermic peaks at around $720^{\circ} \mathrm{C}$ and $850^{\circ} \mathrm{C}$ are attributed to the decomposition of carbonates and the formation of new crystalline phases in high temperatures, respectively (Rovnanik et al., 2013).

\subsection{Leaching behavior}

Seven mixes with different waste bottom ash and granite powder contents were prepared for the leaching tests. The reference sample was alkali activated slag with CEN standard sand as the fine aggregate. All mixes were having a water/binder ratio of 0.5 . The bottom ash replacements of $25 \%, 50 \%$ and a granite powder content of $10 \%$ were used. Samples with the label of "p" mean that a pre-treatment was carried out, namely mixing the activator with bottom ash in advance for $5 \mathrm{~min}$. The purpose of this pre-treatment was to investigate whether the initial contact between bottom ash 

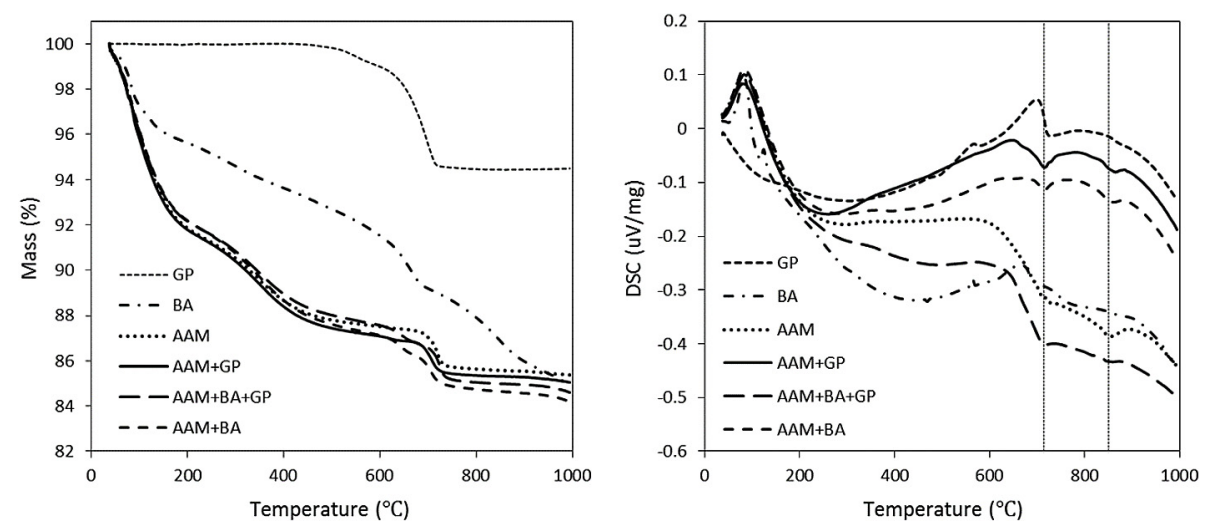

Fig. 9. TG analysis of alkali-activated materials with bottom ash and Granite powder addition.

and concentrated alkali solution has an influence on the leaching behaviors. The other specimens were mixed by the following order: slag, granite powder, sand, bottom ash and then the activator. The leaching results are listed in Table 3 together with the Dutch legislation in non-shaped materials ("Niet-VormGegeven" (NVG)), which regulates the leaching behaviors of granulate materials used for civil technical purposes.

It can be seen that the components in the waste bottom ash above the NVG limitations are $\mathrm{Sb}, \mathrm{Cu}, \mathrm{Mo}, \mathrm{Cl}$ and $\mathrm{SO}_{4}$, including both heavy metals and anions. The detrimental elements' type and content may vary depending on the source of the waste materials. In this study, the Mo concentration in the input waste bottom ash is slightly higher than the legislation, while the $\mathrm{Sb}$ and $\mathrm{Cu}$ contents are around 3 to 4 times higher. In terms of the anions, their concentrations are much higher than the limitation, especially for $\mathrm{Cl}$. It should be noticed that this incinerated bottom ash also contains large amount of $\mathrm{Al}$ ( $12.0 \mathrm{wt}$.\% of $\mathrm{Al}_{2} \mathrm{O}_{3}$ from the XRF analysis), although this element is not in the limitation list, it may cause potential expansion and therefore should be carefully considered in the mix design stage. The leaching results show that when waste bottom ash is applied as partial replacement of the fine aggregate, all mixtures pass the Dutch limitation in the leaching of heavy metals for construction materials, except the leaching of $\mathrm{Cu}$ in samples with a bottom ash content of $50 \%$. For instance, the leached
$\mathrm{Sb}$ in mixes with $50 \%$ bottom ash is around $0.19 \mathrm{mg} / \mathrm{kg}$, which is $40 \%$ lower than the required value; similar phenomenon is observed for $\mathrm{Mo}$, but with lower reduction rate. $\mathrm{Cu}$ is the main leaching issue of this waste bottom ash, because of the extremely high initial content, large amounts addition (50\%) leads to a final high leaching value that exceeds the limitation, except one mix with $50 \%$ bottom ash and $10 \%$ granite. It can be attributed to the testing variations or the sampling. While there is no leaching problem in samples with $25 \%$ bottom ash. It can be seen that in order to reach the leaching regulations, reducing the effective bottom ash content in the final product can be a solution, then the final leaching value is reduced by the dilution effect. In addition, the pretreatment process presents no significant effect on the leaching behaviors, while the initial contact of bottom ash and high alkali solution may play a role in reducing the effect of metallic aluminates. $\mathrm{Cl}$ is highly responsible for the corrosion of steel in reinforced concrete and $\mathrm{SO}_{4}$ is associated with volume stability, thus a pretreatment process is needed to remove those two components before application. A simple water treatment is believed to be highly efficient considering the intrinsic characteristics of $\mathrm{Cl}$ and $\mathrm{SO}_{4}$ being highly mobile in mediums such as water. Actually the washing process is already known to be economically feasible for both $\mathrm{Cl}$ (Boghetich et al., 2005) and $\mathrm{SO}_{4}$ (Abbas et al., 2003). As the normal treatment processes used to remove the heavy metals and $\mathrm{Al}$ can be neglected, a

Table 3

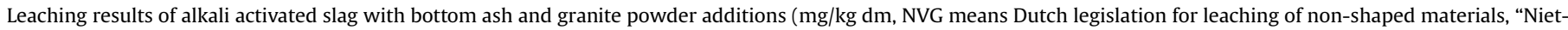
VormGegeven", relating mixtures are shown in Table 2).

\begin{tabular}{|c|c|c|c|c|c|c|c|c|c|}
\hline Items & NVG & $\begin{array}{l}\text { BA } \\
\text { Input }\end{array}$ & $S$ & $\begin{array}{l}S \\
25 B A\end{array}$ & $\begin{array}{l}\text { S } \\
\text { 25BA,p }\end{array}$ & $\begin{array}{l}S \\
50 B A\end{array}$ & $\begin{array}{l}\text { S } \\
\text { 50BA,p }\end{array}$ & $\begin{array}{l}S \\
25 B A \\
10 G\end{array}$ & $\begin{array}{l}S \\
50 B A \\
10 G\end{array}$ \\
\hline $\mathrm{Sb}$ & 0.32 & 1.07 & $<0.039$ & 0.13 & 0.095 & 0.18 & 0.2 & 0.13 & 0.14 \\
\hline As & 0.9 & $<0.05$ & $<0.1$ & $<0.1$ & $<0.1$ & $<0.1$ & $<0.1$ & $<0.1$ & $<0.1$ \\
\hline $\mathrm{Ba}$ & 22 & NA & 0.11 & 0.21 & 0.2 & 0.31 & 0.32 & 0.2 & 0.18 \\
\hline $\mathrm{Cd}$ & 0.04 & $<0.01$ & $<0.01$ & $<0.01$ & $<0.01$ & $<0.01$ & $<0.01$ & $<0.01$ & $<0.01$ \\
\hline $\mathrm{Cr}$ & 0.63 & 0.13 & $<0.1$ & $<0.1$ & $<0.1$ & $<0.1$ & $<0.1$ & $<0.1$ & $<0.1$ \\
\hline Co & 0.54 & $<0.01$ & $<0.1$ & $<0.1$ & $<0.1$ & $<0.1$ & $<0.1$ & $<0.1$ & $<0.1$ \\
\hline $\mathrm{Cu}$ & 0.9 & 4.07 & $<0.1$ & 0.78 & 0.59 & 1.7 & 1.8 & 0.58 & 0.69 \\
\hline $\mathrm{Hg}$ & 0.02 & NA & $<0.001$ & $<0.001$ & $<0.001$ & $<0.001$ & $<0.001$ & $<0.001$ & $<0.001$ \\
\hline $\mathrm{Pb}$ & 2.3 & $<0.05$ & $<0.1$ & $<0.1$ & $<0.1$ & $<0.1$ & $<0.1$ & $<0.1$ & $<0.1$ \\
\hline Mo & 1 & 1.36 & $<0.1$ & 0.37 & 0.42 & 0.64 & 0.57 & 0.27 & 0.36 \\
\hline $\mathrm{Ni}$ & 0.44 & $<0.05$ & $<0.1$ & $<0.1$ & $<0.1$ & $<0.1$ & $<0.1$ & $<0.1$ & $<0.1$ \\
\hline Sn & 0.4 & $<0.05$ & $<0.1$ & $<0.1$ & $<0.1$ & $<0.1$ & $<0.1$ & $<0.1$ & $<0.1$ \\
\hline V & $1,8(1)$ & $<0.01$ & 1.7 & 1.3 & 1.1 & 0.83 & 0.82 & 0.98 & 1.4 \\
\hline $\mathrm{Zn}$ & 4.5 & 0.94 & $<0.2$ & $<0.2$ & $<0.2$ & $<0.2$ & $<0.2$ & $<0.2$ & $<0.2$ \\
\hline $\mathrm{F}$ & $55(2)$ & NA & 9.7 & 7.1 & 6.6 & 7.1 & 6.6 & 5.8 & 7.8 \\
\hline $\mathrm{Br}$ & $20(2)$ & NA & $<2$ & 6.9 & 5.2 & 8.7 & 11 & 5.5 & 6.8 \\
\hline $\mathrm{Cl}$ & $616(2)$ & 6980 & 110 & 1100 & 920 & 1700 & 1900 & 930 & 1000 \\
\hline SO4 & 2430 & 9010 & 1060 & 3810 & 3110 & 6050 & 5820 & 2950 & 3620 \\
\hline
\end{tabular}


more cost effective application potential is foreseen.

\subsection{SEM analysis}

SEM analyses are used to characterize the reaction products with and without wastes solids additions. The mixtures after $28 \mathrm{~d}$ of curing are presented in Fig. 10. Samples with only alkali activated slag (Fig. 10-A) exhibit a homogeneous paste matrix, which can be an indication of a reaction product of high strength in macro scale. The evenly distributed angular shaped phases refer to the partly reacted anhydrous slag particles that are surrounded by the reaction products. As can be seen in Fig. 10-B, when 20\% slag was replaced by granite powder, the shift in microstructure is not significant, and no evident change of phase morphology was observed. This is in line with the gel structure investigations in this study that there is no evident chemical effect of granite powder on the gel characteristics. Thus it can be concluded that the granite powder mainly exhibits a physical filling effect and distributes within the reaction products. The matrix can also be characterized as homogeneous in general.
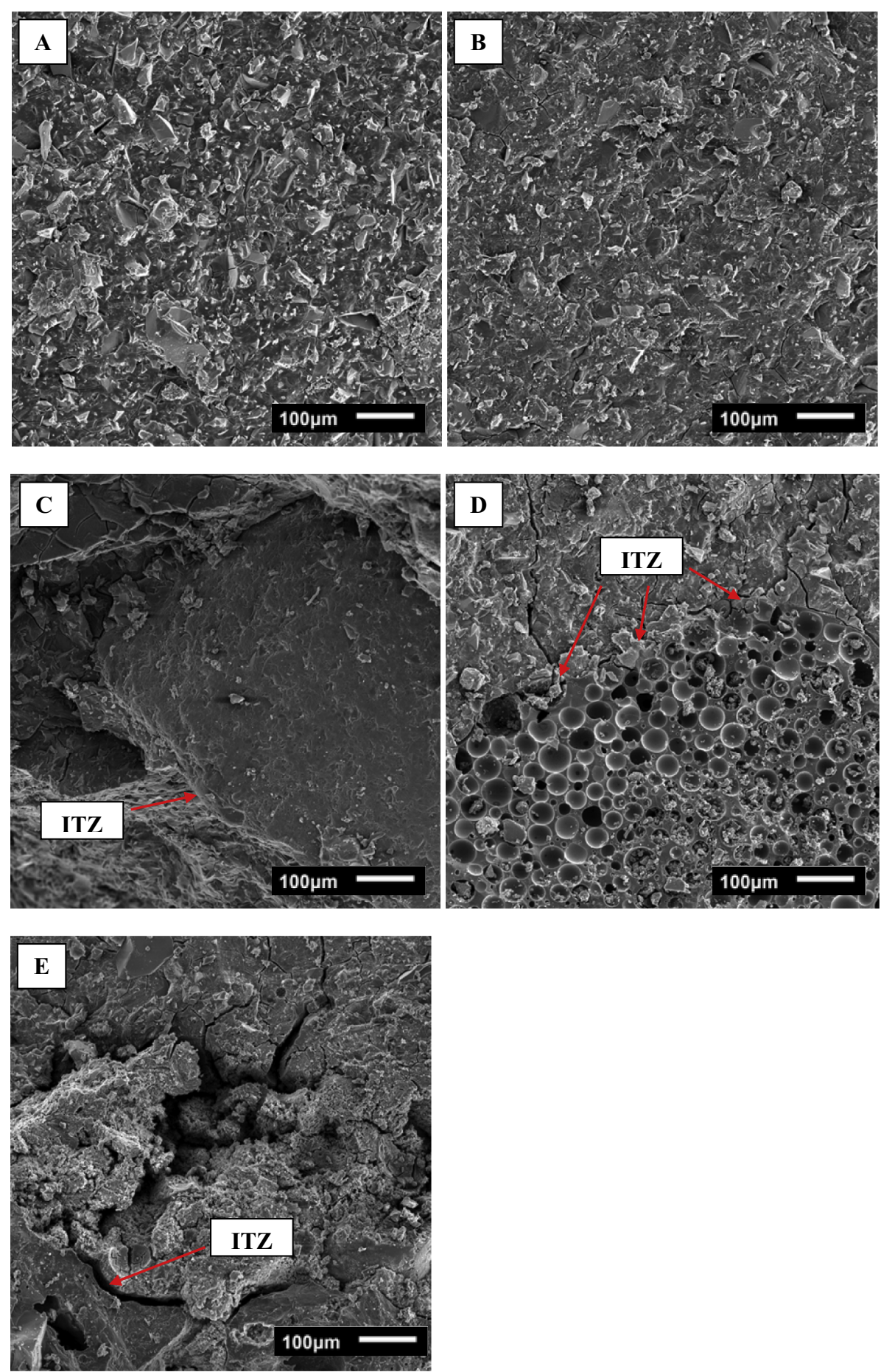

Fig. 10. SEM images of mixtures with bottom ash and Granite powder addition. 
The shifted compressive strength due to the granite powder addition can be attributed to the synergetic effect of several factors such as shifted effective slag dosage, particle packing and the influence of granite particles on the network of reaction products. Fig. 10-C shows the micrograph of alkali activated slag with normal sand addition, working as a reference of mortar samples with commonly used aggregates in construction and building materials. The condensed and homogeneous area on the left side refers to a fine aggregate. The aggregate is well covered by the pastes and a well-connected interfacial transition zone (ITZ) can be observed. The slight cracks on the top area can be attributed to the sample preparation process. In a multi-phased composite such as concrete, the ITZ is the key area in terms of mechanical properties. Fig. 10-D and $\mathrm{E}$ depict two typical conditions of waste bottom ash addition in the alkali activated slag paste. Case D shows a bottom ash with a relatively large particle size and porous structure that works as an aggregate in the matrix, it is clear that compared to the normal sand (Fig. 10-C), this aggregate is more fragile and less condensed. Then it is easy to understand that a lower compressive strength is shown when bottom ash is added, and the loss of strength can be attributed to the nature of the aggregate. The porous structure can also physically absorb a certain amount of activator solution after mixing, and then affect the early age reaction and bound water content to some extent (see the analysis in Sections 3.2 and 3.4). Another typical situation is the effect of bottom ash with smaller sizes, as shown in Fig. 10-E, the bottom ash itself presents an irregular particle shape together with porous structure, which leads to an unsatisfactory bonding in the interfacial transition zone and a heterogeneous matrix in general. Therefore a reduced compressive strength is resulted.

\subsection{Carbon footprint}

A calculation on the $\mathrm{CO}_{2}$ footprint of the resulting mixtures was carried out and the results are shown in Table 4 . The carbon footprint is usually calculated as the sum of the $\mathrm{CO}_{2}$ emissions of each component in unit volume of concrete. In this study, the evaluation was based on a concrete recipe with a binder content of $450 \mathrm{~kg} / \mathrm{m}^{3}$, and a Portland cement based sample was used as a reference. As listed in Table 4, the sodium silicate activator contains $\mathrm{NaOH}$ and commercial waterglass $\left(\mathrm{Na}_{2} \mathrm{O}-\mathrm{nSiO}_{2}-\mathrm{mH}_{2} \mathrm{O}\right)$. Their corresponding contents were determined based on $450 \mathrm{~kg} / \mathrm{m}^{3}$ of binder, and those values were the effective solids contents excluding water. The carbon footprint used in this calculation: $\mathrm{NaOH}\left(1.915 \mathrm{tCO}_{2} / \mathrm{t}\right)$, commercial waterglass $\left(1.514 \mathrm{tCO}_{2} / \mathrm{t}\right), \mathrm{OPC}\left(0.82 \mathrm{tCO}_{2} / \mathrm{t}\right)$, slag $(0.143$ $\left.\mathrm{tCO}_{2} / \mathrm{t}\right)$, fine aggregate $\left(0.0139 \mathrm{tCO}_{2} / \mathrm{t}\right)$, coarse aggregate $(0.0459$ $\mathrm{tCO}_{2} / \mathrm{t}$ ) were obtained from (Collins, 2010; Turner and Collins, 2013). For the waste bottom ash, although a high energy consumption process was involved during the incineration, this process belonged to the life cycle of handling the urban wastes and recycling metals etc., then the "produced" bottom ash can be regarded as a resulting by-product that usually with a negative $\mathrm{CO}_{2}$ footprint value (Allegrini et al., 2015). A similar situation also applied to the granite powder. The $\mathrm{CO}_{2}$ footprint of bottom ash and granite powder was calculated as 0 in this case as a conservative evaluation.

It can be seen from Table 4 that the carbon emission of Portland cement concrete is almost two times of the alkali activated material based concrete, indicating the advantage of using slag as alternative binder in sustainable development. In terms of the alkali activated concrete, the replacement of $50 \%$ bottom ash reduces the total carbon emission by $2.6 \%$. It should be noted that the bottom ash is only used to replace the fine aggregate in this study (i.e. mortar level), while the calculation is based on the concrete level. Moreover, the coarse aggregate consists $21.4 \%$ of the total carbon emission, if the bottom ash is also used to replace coarse aggregate, the $\mathrm{CO}_{2}$ footprint will be further reduced. The addition of $20 \%$ granite powder reduces the total carbon emission by around 6\%. In mixes containing the highest content of granite powder and waste bottom ash, the carbon foot print is reduced by up to $8.6 \%$. Those values can be further lower when a negative impact of bottom ash and granite powder on carbon emission is applied.

\section{Conclusions}

This paper comprises a comprehensive study on reusing MWSI bottom ash and granite powder in alkali activated materials. The waste solids are thoroughly characterized. Besides the key issues in evaluating the waste materials such as mechanical property and leaching behavior, the effect of two solid wastes on early age reaction, gel chemistry and micro structure are identified. Moreover, the $\mathrm{CO}_{2}$ footprint of these alkali activated material-solid waste composites is evaluated. The following conclusions can be drawn based on the results:

- The pre-treatment of the sticky granite powder in water with superplasticizer results in a well dispersed applicable slurry, suggesting a relatively new and cost-effective approach of applying this waste powder.

- Both bottom ash and granite powder slightly delays the early age reaction. But considering no evident effect on gel structure was observed, they can be considered as non-reactive components. Clarifying their effects on reaction kinetics and micro scale properties provide strong basis for further researches and applications.

- Bottom ash negatively influences the strength by its porous structure while granite powder features a filler effect. Compressive strengths of 20-70 MPa can be achieved by using those two solids with waste granite powder content up to $20 \%$ and waste bottom ash content up to $50 \%$, suggesting wide application potentials and high reusing rate of waste materials.

- The leaching of the heavy metals meets the Dutch legislation, confirming again the advantage of using alkali activated binder; while economically feasible methods of treating the chloride and sulfate are suggested since these two chemicals are directly linked to the durability of the final products.

Table 4

Calculation of the carbon footprint of alkali activated slag with bottom ash and granite additions.

\begin{tabular}{|c|c|c|c|c|c|c|c|c|}
\hline \multirow[t]{2}{*}{ Mix } & \multicolumn{7}{|c|}{ Mix proportions $\left(\mathrm{kg} / \mathrm{m}^{3}\right)$} & \multirow[t]{2}{*}{$\mathrm{CO}_{2}$ emissions $\left(\mathrm{tCO}_{2} / \mathrm{t}\right)$} \\
\hline & Binder & $\mathrm{NaOH}$ & waterglass & Granite & BA & Fine aggr. & Coarse aggr. & \\
\hline OPC & 450 & 0 & 0 & 0 & 0 & 800 & 1000 & 0.426 \\
\hline Ref & 450 & 17.1 & 39.74 & 0 & 0 & 800 & & 0.214 \\
\hline BA25 & 450 & 17.1 & 39.74 & 0 & 144 & 600 & & 0.211 \\
\hline BA25 + G20 & 360 & 17.1 & 39.74 & 83.6 & 144 & 600 & & 0.198 \\
\hline BA50 & 450 & 17.1 & 39.74 & 0 & 288 & 400 & & 0.209 \\
\hline BA50 + G20 & 360 & 17.1 & 39.74 & 83.6 & 288 & 400 & & 0.196 \\
\hline
\end{tabular}


- The reuse of these two solid wastes in alkali activated materials not only contributes to sustainable development, reduces the costs of handling the heavy metals and metallic aluminate, but also significantly reduces the total carbon footprint of the final products due to the negative value of the waste materials, indicating another environmental related advantage of applying this sustainable binder-solid waste composites.

\section{Acknowledgements}

This research was supported by Inaschco and Graniet-Import Benelux. X. Gao M.Sc. and B. Yuan M.Sc. are sponsored by the China Scholarship Council (201306950046) and Eindhoven University of Technology (201306950030). The authors wish to express their gratitude to the following sponsors of the Building Materials research group at TU Eindhoven: Rijkswaterstaat Grote Projecten en Onderhoud; Kijlstra Betonmortel; Struyk Verwo; Attero; Enci; Rijkswaterstaat Zee en Delta-District Noord; Van Gansewinkel Minerals; BTE; V.d. Bosch Beton; Selor; GMB; Icopal; BN International; Eltomation; Knauf Gips; Hess AAC Systems; Kronos; Joma; CRH Europe Sustainable Concrete Centre; Cement \& Beton Centrum; Heros; Keim, Sirius International, Boskalis and NNERGY (in chronological order of joining).

\section{References}

Abbas, Z., Moghaddam, A.P., Steenari, B.M., 2003. Release of salts from municipal solid waste combustion residues. Waste Manag. 23, 291-305.

Allegrini, E., Vadenbo, C., Boldrin, A., Astrup, T.F., 2015. Life cycle assessment of resource recovery from municipal solid waste incineration bottom ash. J. Environ. Manag. 151, 132-143.

Aubert, J.E., Husson, B., Vaquier, A., 2004. Metallic aluminum in MSWI fly ash: quantification and influence on the properties of cement-based products. Waste Manag. 24, 589-596.

Bernal, S.A., Provis, J.L., Rose, V., Gutierrez, R.M., 2011. Evolution of binder structure in sodium silicate-activated slag-metakaolin blends. Cem. Concr. Compos. 33 46-54.

Bernal, S.A., Gutierrez, R.M., Provis, J.L., 2012. Engineering and durability properties of concretes based on alkali-activated granulated blast furnace slag/metakaolin blends. Constr. Build. Mater. 33, 99-108.

Bertolini, L., Carsana, M., Cassago, D., Curzio, A., Collepardi, M., 2004. MSWI ashes as mineral additions in concrete. Cem. Concr. Res. 34, 1899-1906.

Birgisdottir, H., Pihl, K.A., Bhander, G., Hauschild, M.Z., Christensen, T.H., 2006. Environmental assessment of roads constructed with and without bottom ash from municipal solid waste incineration. Transp. Res. Part. D 11, 358-368.

Bobrowski, A., Kmita, A., Starowicz, M., Stypuła, B., Hutera, B., 2012. Effect of magnesium oxide nanoparticles on water glass structure. Arch. Found. Eng. 12 (3), 9-12.

Boghetich, G., Liberti, L., Natarnicola, M., Palma, M., Petruzzelli, D., 2005. Chloride extraction for quality improvement of municipal solid waste incinerator ash fo the concrete industry. Waste Manag. Res. 23, 57-61.

Bonavetti, V.L., Rahhal, V.F., Irassar, E.F., 2001. Studies on the carboaluminate formation in limestone filler-blended cements. Cem. Concr. Res. 31, 853-859.

Bosmans, A., Vanderreydt, I., Geysen, D., Helsen, L., 2013. The crucial role of wasteto energy technologies in enhanced landfill mining: a technology review. J. Clean. Prod. 55, 10-23.

British standard EN 196-1, 2005. Methods of Testing Cement Part 1: Determination of Strength.

British standard EN 933-1, 1997. Tests for Geometrical Properties of Aggregates, Determination of Particle Size Distribution, Sieving Method.

Capros, P., Kouvaritakis, N., Mantzos, L., 2001. Economic Evaluation of Sectorial Emission Reduction Objectives for Climate Change Top-down Analysis of Greenhouse Gas Emission Possibilities in the EU. European Commission.

Chen, Z.T., Liu, Y.Q., Zhu, W.P., Yang, E.H., 2016. Incinerator bottom ash (IBA) aerated geopolymer. Constr. Build. Mater. 112, 1025-1031.

Chimenos, J.M., Segarra, M., Fernandez, M.A., Espiell, F., 1999. Characterization of the bottom ash in a municipal solid waste incinerator. J. Hazard. Mater. 64, $211-222$

Cimpan, C., Wenzel, H., 2013. Energy implications of mechanical and mechanicalbiological treatment compared to direct waste-to-energy. Waste Manag. 33, 1648-1658.

Collins, F, 2010. Inclusion of carbonation during the life cycle of built and recycled concrete: influence on their carbon footprint. Int. J. Life Cycle Assess. 15, $549-556$.
Eikelboom, R.T., Ruwiel, E., Goumans, J.J., 2001. The building materials decree: an example of a Dutch regulation based on the potential impact of materials on the environment. Waste Manag. 21, 295-302.

Forteza, R., Far, M., Segui, C., Cerda, V., 2004. Characterization of bottom ash in municipal solid waste incinerators for its use in road base. Waste Manag. 24, 899-909.

Friedlingstein, P., Houghton, R.A., Marland, G., Hackler, J., Boden, T.A., Conway, T.J., 2010. Uptake on $\mathrm{CO}_{2}$ emissions. Nat. Geosci. 3, 811-812.

Gao, X., Yu, Q.L., Brouwers, H.J.H., 2015. Reaction kinetics, gel character and strength of ambient temperature cured alkali activated slag-fly ash blends. Constr. Build. Mater. 80, 105-115.

Hajimohammadi, A., Provis, J.L., Deventer, J.S.J., 2011. Time-resolved and spatially resolved infrared spectroscopic observation of seeded nucleation controlling geopolymer gel formation. J. Colloid. Interface. Sci. 357, 384-392.

Hjelmar, O., Holm, J., Crillesen, K., 2007. Utilisation of MSWI bottom ash as sub-base in road construction: first results from a large-scale test site. J. Hazard. Mater. 139, $471-480$.

Huiskes, D.M.A., Keulen, A., Yu, Q.L., Brouwers, H.J.H., 2016. Design and performance evaluation of ultra-lightweight geopolymer concrete. Mater. Des. 89, 516-526.

Ismail, I., Bernal, S.A., Provis, J.L., Nicolas, R.S., Hamdan, S., Deventer, J.S.J., 2014. Modification of phase evolution in alkali-activated blast furnace slag by the incorporation of fly ash. Cem. Concr. Compos. 45, 125-135.

ISO 13320, 2009. Particle Size Analysis - Laser Diffraction Methods.

Jan, D., 2002. Immobilization of $\mathrm{Cr}^{6+}, \mathrm{Cd}^{2+}, \mathrm{Zn}^{2+}$ and $\mathrm{Pb}^{2+}$ in alkali-activated slag binders. Cem. Concr. Res. 32, 1671-1679.

Juric, B., Hanzic, L., Ilic, R., Samec, N., 2006. Utilization of municipal solid waste bottom ash and recycled aggregate in concrete. Waste Manag. 26, 1436-1442.

Kovalchuk, G., Fernandez, A., Palomo, A., 2007. Alkali-activated fly ash: effect of thermal curing conditions on mechanical and microstructural development Part II. Fuel 86, 315-322.

Lancellotti, I., Ponzoni, C., Barbieri, L., Leonelli, C., 2013. Alkali activation processes for incinerator residues management. Waste Manag. 33, 1740-1749.

Lee, H.K., Kim, H.K., Hwang, E.A., 2010. Utilization of power plant bottom ash as aggregates in fibre-reinforced cellular concrete. Waste Manag. 30, 274-284.

Li, C., Sun, H.H., Li, L.T., 2010. A review: the comparison between alkali activated slag $(\mathrm{Si}+\mathrm{Ca})$ and metakaolin $(\mathrm{Si}+\mathrm{Al})$ cements. Cem. Concr. Res. 40, 1341-1349.

NEN 7383, 2003. Uitloogkarakteristieken-Bepaling van de cumulatieve uitloging van anorganische componenten uit poeder-en korrelvormige materialen met een vereenvoudigde procedure voor de kolomproef - vaste gronden steenachtige materialen (in Dutch).

NEN 6966, 2005. Environment-analysis of Selected Elements in Water, Evaluates and Destruates - Atomic Emission Spectrometry with Inductively Coupled Plasma.

NEN 10304-2, 1996. Water Quality: Determination of Dissolved Anions by Liquid Chromatography of Ions. Part 2: Determination of Bromide, Chloride, Nitrate, Nitrite, Orthophosphate and Sulfate in Waste Water.

Rovnanik, P., Bayer, P., Rovnanikova, P., 2013. Characterization of alkali activated slag paste after exposure to high temperatures. Constr. Build. Mater. 47, 1479-1487.

Rozineide, A., Santa, A.B., Soares, C., Riella, H.G., 2016. Geopolymers with a high percentage of bottom ash for solidification/immobilization of different toxic metals. J. Hazard. Mater. 318, 145-153.

Shi, C., Day, R.L., 1995. A calorimetric study of early hydration of alkali-slag cements. Cem. Concr. Res. 25, 1333-1346.

Soil Quality Decree, 2008. https://zoek.officielebekendmakingen.nl/stb-2/.

Song, Q., Wang, Z., Li, J., 2013. Environmental performance of municipal solid waste strategies based on LCA method: a case study of Macau. J. Clean. Prod. 57, 92-100.

Tang, P., Florea, M.V.A., Spiesz, P., Brouwers, H.J.H., 2016. Application of thermally activated municipal solid waste incineration (MWSI) bottom ash fines as binder substitute. Cem. Concr. Compos. 70, 194-205.

Turner, L.K., Collins, F.G., 2013. Carbon dioxide equivalent $\left(\mathrm{CO}_{2}-\mathrm{e}\right)$ emissions: a comparison between geopolymer and OPC cement concrete. Constr. Build. Mater. 43, 125-130.

UNSTATS, 2010. Greenhouse Gas Emissions by Sector (Absolute Values). United Nation Statistical Division: Springer.

Wang, S.D., Scrivener, K.L., Pratt, P.L., 1994. Factors affecting the strength of alkaliactivated slag. Cem. Concr. Res. 24 (6), 1033-1043.

Weil, M., Dombrowski, K., Buchawald, A., 2009. Geopolymers, Structure, Processing, Properties and Applications. Woodhead Publishing Limited, Abington Hall, pp. 194-210.

Wiles, C.C., 1996. Municipal solid waste combustion ash: state-of-the-knowledge. J. Hazard. Mater. 47, 325-344.

Xie, T.Y., Ozbakkaloglu, T., 2015. Behavior of low-calcium fly and bottom ash-based geopolymer concrete cured at ambient temperature. Ceram. Int. 41 (4), 5945-5958.

Yousuf, M. Mollah, A., Hess, T.R., Tsai, Y.N., Cocke, D.L., 1993. An FTIR and XPS Investigations of the effects of carbonation on the solidification/stabilization of cement based systems-portland type V with zinc. Cem. Concr. Res. 23 (4), 773-784.

Zhang, Y.S., Sun, W., Chen, Q.L., Chen, L., 2007. Synthesis and heavy metal immobilization behaviors of slag based geopolymer. J. Hazard. Mater 143, 206-213. 